Franc TRČEK

\title{
Sociološka anketna raziskava Prenova stanovanjskih sosesk v Ljubljani - Savsko naselje
}

Prenova soseske Participacija stanovalcev Bivalno okolje Stanovanjske preference

Anketa

Prostorska

sociologija

Savsko naselje

Ljubljana

Renewal of housing estates Participation by residents

Living

environment

Housing

preference

Survey

Spatial sociology

Savsko naselje

Ljubljana
V prispevku predstavljamo ključne ugotovitve sociološke anketne raziskave Prenova stanovanjskih sosesk v Ljubljani - Savsko naselje. Osredotočila se je na mnenja in stališča stanovalcev o soseski ter predvidela njihove prihodnje stanovanjske preference. Ključni problem - ob izrazitem nezaupanju tako do MOL kot tudi do interdisciplinarne skupine strokovnjakov, vključene $v$ raziskovalni projekt - je predvsem finančna nezmožnost financiranja prenove stanovalcev ob hkratnem burnem zavračanju možnosti sofinanciranja prenove $z$ nadgradnjami in novogradnjami. Rezultati ankete kažejo, da se bo brez izvedene celovite prenove, ki bo vključevala tudi sprejemljivo finančno-kreditno politiko, v naslednjem desetletju zmanjšala kakovost vzdrževanja ter s tem posledično padla vrednost nepremičnin $v$ soseski.

\section{Izhodišča sociološke ankete}

V izhodišču raziskovalnega projekta Prenova stanovanjskih sosesk v Ljubljani - Savsko naselje je bila predvidena sociološka anketa, ki naj bi zajela mnenja in stališča stanovalcev soseske o svojem bivalnem okolju ter njihove (prihodnje) stanovanjske preference. Priprava anketnega vprašalnika, izvedba ankete, oblikovanje podatkovne baze ter anali$\mathrm{za}$ in interpretacija rezultatov so bili zaupani sodelavcem Centra za prostorsko sociologijo s Fakultete za družbene vede.

Vprašalnik, izhajajoč iz načrta raziskovalnega projekta, tematsko obsega naslednje sklope:

- oceno bivanjske kakovosti in urejenosti celotne soseske,

- sklop o prenovi soseske,

- sklop o bivanjski kakovosti stavbe in predvsem stanovanja, v katerem biva anketiranec, vključno z vprašanji o prenovah na
The article presents some key findings of the sociological survey research Rehabilitation of housing estates in Ljubljana - Savsko naselje. It focused on attitudes and opinions of the estate's residents and estimated their future residential preferences. The key issue - coupled with significant distrust of the local authority as well as the interdisciplinary group of experts conducting the research - was above all the inability of the residents to finance rehabilitation, but also their vigourous resentment of any co-financing that would entail extensions or even new construction. The survey results show that, if the rehabilitation process is not undertaken comprehensively, including acceptable financialloan arrangements, in the next decade the quality of maintenance will drop and consequentially the value of property in the neighbourhood.

objektu in v stanovanju $\mathrm{v}$ zadnjih petih letih ter o načrtovanih prenovah,

- sklop o prihodnjih stanovanjskih preferencah anketirancev

- ter demografijo, ki vsebuje tudi vprašanja o času bivanja $\mathrm{v}$ soseski in razlogih priselitve vanjo.

Ob navedenih sklopih smo anketirancem dali tudi možnost, da nam ob koncu ankete sporočijo svoje osebne poglede na teme, ki niso dovolj obsežno zajete $v$ vprašanjih, ter nam posredujejo po njihovem mnenju še dodatne informacije, nanašajoče se na tematiko raziskovalnega projekta.

\section{Metodologija in izvedba ankete}

Izhajajoč iz dejstva, da soseska, ki je predmet raziskovanja, po popisu iz leta 1991 obsega nekaj več kot 1200 stanovanj, ter da je 
enota naše raziskave dejansko gospodinjstvo, smo se odločili za metodo naključnega vzorca (Glej Thompson, 2002) ter izvedbo anketiranja v polovici vseh $\mathrm{v}$ anketni okoliš zajetih stanovanjskih enot.

Zaradi morebitnih težav z izgovarjanjem v naključni vzorec zajetih anketirancev, da »trenutno nimajo časa $\mathrm{za}$ anketiranje «, in izhajajoč iz dobrih izkušenj s samoanketiranjem pri izvedbi anketne raziskave s sorodno tematiko Re-Urban Mobil (2004), ki smo jo izvedli v Stari Ljubljani, smo se odločili za enak pristop. To pomeni, da je anketar izročil vprašalnik naključno izbranemu anketirancu in se $z$ njim dogovoril, kdaj ga bo prevzel. Anketiranec ga je nato sam izpolnil $\mathrm{v}$ približno 20 minutah. Anketarjeva naloga ob prevzemu vprašalnika pa je bila, da preveri pravilnost izpolnjevanja.

Anketiranje je potekalo brez večjih težav v drugi polovici maja 2004. Anketarjem je bilo dano 700 vprašalnikov, od tega je bilo uspešno razdeljenih 650. Vrnjenih je bilo 584, kar pomeni, da je bila realizacija 90odstotna. Tako velik delež odziva lahko pojasnjujemo na eni strani s tematiko vprašalnika, ki neposredno zadeva vsakdanje bivanje anketirancev, na drugi strani pa tudi $\mathrm{z}$ njihovim strahom, da naročnik ne bi »spet nekaj gradil mimo njihove volje « v njihovi »lepi, zeleni, bivanjsko privlačni soseski«, kar lahko preberemo iz sporočil naročnikom in izvajalcem raziskave, podanih ob koncu vprašalnika.

Pri oblikovanju podatkovne baze $\mathrm{z}$ rezultati ankete smo bili prisiljeni število enot skrčiti na 553. Razlog za izločitev 32 vprašalnikov pri oblikovanju podatkovne baze je v dejstvu, da nekateri anketiranci niso bili pripravljeni odgovarjati na osnovna vprašanja iz demografskega sklopa (spol, starost, število družinskih članov, izobrazba, delovni status ...), ker po njihovem mnenju »to ni področje, ki zadeva prenovo« oziroma v manj vljudnih izjavah podano »vas to nič ne briga«. Brez osnovnih demografskih podatkov o anketirancu in članih njegovega gospodinjstva ne moremo uporabljati odgovorov na druga vprašanja $\mathrm{v}$ analizah, zato smo takšne nepopolne vprašalnike izločili. Upoštevali smo v njih podane odgovore na odprta vprašanja pri analizi vsebin odprtih vprašanj.

\section{Analiza rezultatov sociološke ankete}

V nadaljevanju podajamo analizo rezultatov po posameznih tematskih sklopih. Ob analizi sumarnika je bila izvedena tudi vrsta tematskih križanj spremenljivk. Statistično pomembna in predvsem raziskovalno oziroma projektno bistvena spoznanja, ki smo jih dobili s križanji spremenljivk, so podana znotraj analiz posameznih tematskih sklopov. Za nadaljevanje projekta prenove najpomembnejša spoznanja pa so dodatno podana še v sklepu.

\subsection{Ocena bivalne kakovosti in urejenosti soseske}

V uvodnem tematskem sklopu smo anketirancem postavili blok vprašanj, ki se nanašajo na njihovo oceno bivalne kakovosti soseske. Najprej smo jih vprašali »Ali bi priporočili nekomu, ki ne pozna vaše soseske, da se preseli vanjo? " in dobili veliki dve tretjini pritrdilnih odgovorov ob precej velikem odstotku neopredeljenih $(21,2)$. Le osmina anketirancev bi odsvetovala priselitev $\mathrm{v}$ svojo sosesko. Glede na demografske značilnosti izstopajo med tistimi, ki bi priporočili priselitev, anketiranci z večjimi skupnimi mesečnimi dohodki na gospodinjstvo, kar je običajno povezano tudi $\mathrm{z}$ dejstvom, da gre za tri- ali štiričlanska gospodinjstva, navadno sestavljena iz staršev in otrok.

V nadaljevanju sklopa smo želeli od anketirancev dobiti njihovo mnenje o (primerjalni) urejenosti soseske z vprašanjem »Kako bi vi ocenili urejenost svoje soseske? « in »Če primerjate svojo sosesko $z$ drugimi ljubljanskimi stanovanjskimi naselji, ali se vam zdi vaša soseska ... « Iz rezultatov, podanih v tabeli 1 in 2, lahko vidimo, da imajo svojo sosesko prej za urejeno kot neurejeno. Res pa je, da je precej velik delež niti - niti pri prvem vprašanju in velik delež »podobno kot večina drugih sosesk $v$ Ljubljani pri drugem vprašanju. Razloge za dokaj strogo oceno kakovosti bivalnega okolja lahko vidimo v vprašanju o (ne) zadovoljstvu z značilnostmi soseske ter motečimi pojavi ter tudi $\mathrm{v}$ analizi vsebin odprtih vprašanj, kjer se izkaže, da se stanovalci na eni strani zavedajo dokaj majhne gostote gradnje ter obilja zelenih površin kot primer- 
jalnih odlik, na drugi strani pa so ob stihijskem parkiranju ravno slabo vzdrževanje zelenih površin, vključno z otroškimi igrišči, ter onesnaženje ulic s smetmi in pasjimi iztrebki tisto, kar po njihovem mnenju zmanj-

Preglednica 1: Urejenost soseske

\begin{tabular}{|l|r|}
\hline 1. Zelo neurejena & $2,9 \%$ \\
\hline 2. Neurejena & $9,1 \%$ \\
\hline 3. Niti urejena niti neurejena & $41,0 \%$ \\
\hline 4. Urejena & $44,3 \%$ \\
\hline 5. Zelo urejena & $2,7 \%$ \\
\hline
\end{tabular}

Preglednica 2: Primerjava soseske z drugimi naselji $\vee$ Ljubljani

\begin{tabular}{|l|r|}
\hline 1. Precej bolj zanemarjena & $2,2 \%$ \\
\hline 2. Bolj zanemarjena & $6,9 \%$ \\
\hline $\begin{array}{l}\text { 3. Podobna kot večina drugih } \\
\text { sosesk v Ljubljani }\end{array}$ & $58,8 \%$ \\
\hline 4. Bolj urejena & $29,7 \%$ \\
\hline 5. Precej bolj urejena & $2,4 \%$ \\
\hline
\end{tabular}

Preglednica 3: (Ne)zadovoljstvo z značilnostmi soseske

\begin{tabular}{|l|c|c|c|c|}
\hline & $\begin{array}{c}\text { Zelo } \\
\text { nezado- } \\
\text { voljen } \\
\%\end{array}$ & $\begin{array}{c}\text { Delno } \\
\text { nezado- } \\
\text { voljen } \\
\%\end{array}$ & $\begin{array}{c}\text { Se kar } \\
\text { zadovo- } \\
\text { ljen } \\
\%\end{array}$ & $\begin{array}{c}\text { Zelo } \\
\text { zadovo- } \\
\text { ljen } \\
\%\end{array}$ \\
\hline 1. Podobo soseske & 5,3 & 25,4 & 61,1 & 8,2 \\
\hline 2. Gostoto soseske & 13,7 & 32,8 & 43,0 & 10,6 \\
\hline 3. Javnim potniškim prometom & 6,6 & 18,2 & 46,8 & 28,4 \\
\hline $\begin{array}{l}\text { 4. Urejenostjo javnih zelenih } \\
\text { površin }\end{array}$ & 13,5 & 26,8 & 47,2 & 12,5 \\
\hline 5. Urejenostjo prometa v soseski & 28,3 & 32,6 & 32,6 & 6,5 \\
\hline 6. Stanjem cest in poti & 10,0 & 27,4 & 53,6 & 9,0 \\
\hline 7. Parkirišči & 60,2 & 23,7 & 12,0 & 4,1 \\
\hline 8. Zbiranjem in odvozom & 3,9 & 17,1 & 55,6 & 23,4 \\
\hline odpadkov & & & & \\
\hline 9. Vrtcem in osnovno šolo & 5,2 & 8,8 & 47,7 & 38,3 \\
\hline 10. Otroškimi igrišči & 23,4 & 28,3 & 33,6 & 14,7 \\
\hline 11. Možnostmi športa in rekreacije & 22,9 & 35,9 & 34,8 & 6,4 \\
\hline 12. Trgovinsko ponudbo & 5,4 & 12,5 & 52,2 & 29,8 \\
\hline 13. Gostinsko ponudbo & 6,2 & 12,6 & 58,1 & 23,1 \\
\hline 14. Čistostjo soseske & 10,5 & 31,7 & 51,2 & 6,6 \\
\hline 15. Vzdrževanjem stavb v soseski & 8,9 & 29,8 & 53,8 & 7,4 \\
\hline 16. Upravljanjem vaše stavbe & 15,2 & 27,1 & 44,2 & 13,5 \\
\hline 17. Mirnostjo soseske & 12,1 & 22,4 & 48,1 & 17,4 \\
\hline 18. Kakovostjo zraka & 13,5 & 28,6 & 48,7 & 9,2 \\
\hline 19. S sostanovalci & 5,0 & 18,3 & 56,9 & 19,8 \\
\hline 20. Varnostjo v soseski & 10,5 & 27,0 & 52,7 & 9,8 \\
\hline & & & & \\
\hline
\end{tabular}

šuje potencialno (primerjalno) kakovost njihovega bivalnega okolja. Zanimivo je, da sosesko vrednotijo kot bolj urejeno anketiranci, ki bivajo v najemnih in neprofitnih stanovanjih.

Ob oceni kakovosti soseske nas je zanimala tudi identifikacija stanovalcev z njo. Kljub pogostim, včasih tudi lirično navdihnjenim opisom »zelene in mirne soseske « oziroma »ob Prulah edine še neuničene soseske v centru Ljubljane « v bližini »grozne Zupančičeve jame« v zadnjem vprašanju in prevladujočim podobnim izjavam na delavnici $\mathrm{s}$ stanovalci je presenetljivo nizka stopnja povezanosti s sosesko. Kar tri četrtine anketirancev se ne čuti preveč močno povezanih $z$ njo (53,4 odstotka) ali pa sploh ne (20,6 odstotka). Na drugi strani pa se jih le 3,6 odstotka čuti zelo močno povezanih in 22,4 močno povezanih s sosesko. Iz analize je razvidno, da se z njo identificirajo predvsem starejši prebivalci, ki praviloma dlje bivajo $\mathrm{v}$ njej, ter zelo izstopajoče tisti, ki že ves čas živijo tam (kar 53,6 odstotka od njih se jih čuti močno povezanih s svojo sosesko). Praviloma gre pri obeh skupinah anketirancev za lastnike stanovanj in ne za najemnike ali podnajemnike.

Sklop o oceni kakovosti soseske končujeta vprašanji, ki se nanašata na oceno posameznih značilnosti soseske ter na pogostost motečih pojavov v njej. Iz preglednice 3 je razvidno, da so anketiranci - $z$ izjemo problema nezadostnih parkirišč $-\mathrm{v}$ celoti gledano (še kar) zadovoljni z večino značilnosti svoje soseske. Ob parkiranju in urejenosti prometa so nezadovoljni zlasti še z neurejenostjo otroških igrišč in pomanjkanjem možnosti za šport in rekreacijo ter delno nezadovoljni $\mathrm{z}$ gostoto poselitve in čistostjo soseske ter (ne) urejenostjo javnih zelenih površin. Večina ne pogreša trgovinsko-gostinske ponudbe, ker te potrebe zadovoljujejo predvsem $v$ bližnji Zupančičevi jami.

Ocena problematičnih značilnosti soseske se identično ponovi tudi $v$ oceni motečih pojavov v soseski, kjer je spet najočitnejša celotna problematika prometa (nezadostne parkirne površine, prometni zastoji, prometni hrup). Ob tem se pojavlja še problematika slabe urejenosti javnih površin (slabo vzdrževana otroška igrišča, onesnaženje ulic in zelenic). Iz odgovorov je razvidno, da gre za sosesko z dokaj malo vandalizma. (Preglednica 4) 
V celoti gledano nam sklop vprašanj o oceni kakovosti soseske kaže, da jo anketiranci vseeno vrednotijo kot kakovostno, čeprav se ne čutijo pretirano povezani $z$ njo, a se hkrati zavedajo, kje so problemi, zaradi katerih je manj privlačna. Iz analize križanj so pri ocenah lastnosti soseske razvidna generacijska in slojna razhajanja. Tako je med mlajšimi anketiranci več tistih, ki pogrešajo možnosti za šport in rekreacijo, in mlajši anketiranci sestavljajo tudi večino (številno sicer majhne) manjšine, ki pogreša več gostinske in trgovinske ponudbe.

Stopnja navezanosti na sosesko pa je ob času bivanja v njej in lastništvom stanovanj odvisna predvsem od dohodkovne in slojne pripadnosti anketirancev, kjer se tisti $z$ večjimi dohodki in izobrazbo čutijo manj povezani $\mathrm{z}$ njo.

\subsection{Prenova soseske}

Oceni kakovosti soseske sledi osrednji sklop vprašalnika, ki se nanaša na problematiko prenove soseske. Uvodno vprašanje $\mathrm{v}$ sklop »Glede na dejstvo, da je bila vaša soseska zgrajena že pred leti, ali menite, da bi bila kot celota potrebna prenove? « kaže, da se skoraj dve tretjini anketirancev (zelo nujno potrebna prenove 14,4 odstotka, nujno potrebna prenove 48,9) zavedata nujnosti prenove, dobra tretjina pa meni, da prenova ni potrebna (prenova ni potrebna 28,4 odstotka, prenova splob ni potrebna 8,3 odstotka), 14,4 odstotka pa se jih ne more odločiti. V skupino, ki meni, da je prenova potrebna, spadajo ob tistih, ki že od rojstva bivajo v soseski, predvsem mlajši, delovno aktivni anketiranci, ki so praviloma tudi iz dohodkovno bolje stoječih tri- in štiričlanskih dvogeneracijskih gospodinjstev, ter tisti, ki bivajo v njej manj kot 15 let. Med anketiranci, ki menijo, da prenova (sploh) ni potrebna, pa prevladujejo starejši in upokojenci iz eno- in dvočlanskih gospodinjstev ter anketiranci z manjšimi dohodki ter nižjo doseženo stopnjo izobrazbe.

Ob mnenju o prenovi smo želeli izvedeti tudi, ali so stanovalci pripravljeni sodelovati pri prenovi ter kdo naj jo vodi, zato smo postavili vprašanji »Ali bi bili vi osebno pripravljeni sodelovati pri prenovi? « in »Kdo naj po vašem mnenju vodi prenovo soseske? «

Pri pripravljenosti sodelovanja je polovica anketirancev (49,4 odstotka) odgovorila, da ne ve oz. ni razmišljala o tem, 23,4 odstotka jih ni pripravljeno sodelovati pri prenovi, 27,2 odstotka pa je izrazilo željo po osebnem sodelovanju. Iz analiz križanj spremenljivk je razvidno, da bi bili pri prenovi pripravljeni osebno sodelovati anketiranci, ki so zaposleni in od nekdaj živijo $\mathrm{v}$ soseski ali pa $\mathrm{v}$ njej prebivajo od 6 do 30 let, spadajo v gospodinjstva $Z$ večjim skupnim mesečnim dohodkom ter bivajo v lastniških ali neprofitnih stanovanjih $\mathrm{v}$ tri- in veččlanskih gospodinjstvih. Med starostnimi skupinami izstopa skupina anketirancev, starih od 31 do 40 let, ki izraža veliko pripravljenost za osebno sodelovanje v prenovi. Stopnja pripravljenosti se povišuje tudi s stopnjo izobrazbe. Med polovico, ki ne ve oziroma o tem še ni razmišljala, je nekoliko več starejših, manj izobraženih in tistih, ki živijo manj časa v soseski.

$\mathrm{Na}$ vprašanje o načinu vodenja prenove se jih je dobra polovica $(51,9$ odstotka) odločila za predlog skupine, sestavljene iz predstavnikov stanovalcev in vseh $v$ proces prenove vključenih strok, slaba četrtina (23,2 odstotka) pa bi vodenje prenove prepustila pristojnim službam MOL. Analiza križanj kaže, da se za predlog interdisciplinarne skupine odločajo anketiranci, ki so po karakteristikah podobni anketirancem, ki izražajo pripravljenost na osebno sodelovanje $\mathrm{v}$ prenovi. Vodenje prenove bi pri-

Preglednica 4: Pogostost motečih pojavov

\begin{tabular}{|l|c|c|c|c|}
\hline & $\begin{array}{c}\text { Nikoli } \\
\%\end{array}$ & $\begin{array}{c}\text { Včasih } \\
\%\end{array}$ & $\begin{array}{c}\text { Pogosto } \\
\%\end{array}$ & $\begin{array}{c}\text { Ne- } \\
\text { nehno } \\
\%\end{array}$ \\
\hline 1. Slabo vzdrževana otroška igrišča & 8,0 & 42,1 & 30,6 & 19,3 \\
\hline 2. Prometni zastoji & 19,9 & 39,8 & 30,0 & 10,3 \\
\hline 3. Hrup sosedov & 18,6 & 57,6 & 18,6 & 5,3 \\
\hline 4. Hrup mimoidočih & 18,5 & 54,1 & 21,2 & 6,2 \\
\hline $\begin{array}{l}\text { 5. Hrup iz trgovin, restavracij in } \\
\text { klubov }\end{array}$ & 65,8 & 26,2 & 6,5 & 1,5 \\
\hline 6. Grafiti na zidovih & 37,9 & 48,0 & 11,4 & 2,7 \\
\hline 7. Nezadostne parkirne površine & 4,9 & 15,9 & 19,5 & 59,7 \\
\hline $\begin{array}{l}\text { 8. Onesnaženje ulic } \\
\text { (smeti, pasji iztrebki) }\end{array}$ & 6,4 & 35,1 & 32,3 & 26,3 \\
\hline 9. Onesnaženje zelenic & 7,7 & 41,0 & 32,0 & 19,3 \\
\hline 10. Prometni hrup & 14,3 & 40,7 & 23,5 & 21,6 \\
\hline 11. Kraja ali uničenje poštnih pošiljk & 60,3 & 32,4 & 5,5 & 1,7 \\
\hline $\begin{array}{l}\text { 12. Vlomi v avtomobile } \\
\text { (tudi poskusi) }\end{array}$ & 16,4 & 57,7 & 20,2 & 5,7 \\
\hline 13. Vlomi v kleti (tudi poskusi) & 27,0 & 58,0 & 11,8 & 3,2 \\
\hline $\begin{array}{l}\text { 14. Vlomi v stanovanja } \\
\text { (tudi poskusi) }\end{array}$ & 39,4 & 52,6 & 5,7 & 2,3 \\
\hline 15. Smrad izpušnih plinov & 19,0 & 40,6 & 22,4 & 18,0 \\
\hline
\end{tabular}


stojnim službam MOL prepustili starejši, manj izobraženi, anketiranci, ki bivajo v neprofitnih in najetih stanovanjih ter v dohodkovno manj premožnih gospodinjstvih.

V sklop o prenovi smo vključili tudi kontrolno vprašanje, ki se glasi: »Izkušnje mnogo mest kažejo, da v slabo vzdrževanih soseskah vrednost nepremičnin (stanovanj) pada. Ali mislite, da se to labko zgodi tudi vaši soseski? "S tem vprašanjem preverjamo, koliko se anketiranci dejansko zavedajo Življenjskega cikla soseske, s katerim je povezana tudi vrednost nepremičnin. Odgovori na kontrolno vprašanje kažejo, da skoraj dve tretjini anketirancev (62,7 odstotka) menita,

Preglednica 5: Kaj bi bilo treba prenoviti oziroma na novo zgraditi? (Top 12)

\begin{tabular}{|l|c|c|c|}
\hline & $\begin{array}{c}\text { Treba je } \\
\%\end{array}$ & $\begin{array}{c}\text { Niti - } \\
\text { niti } \\
\%\end{array}$ & $\begin{array}{c}\text { Ni treba } \\
\%\end{array}$ \\
\hline 1. Otroška igrišča & 69,3 & 14,5 & 16,2 \\
\hline 2. Javne zelene površine & 67,6 & 16,8 & 15,7 \\
\hline 3. Spodbujati stanovalce k urejanju okolice & 67,0 & 21,2 & 15,3 \\
\hline 4. Komunalna služba naj bolje ureja okolico & 65,8 & 19,2 & 15,0 \\
\hline 5. Zgraditi garažne hiše & 64,7 & 15,8 & 19,5 \\
\hline 6. Urediti nova pročelja, fasade & 60,1 & 17,5 & 22,4 \\
\hline 7. Urediti varovana stanovanja & 55,2 & 23,3 & 20,5 \\
\hline 8. Izboljšati varnost z videonadzorom & 52,8 & 21,5 & 26,1 \\
\hline 9. Odpreti e-točko & 50,4 & 23,8 & 25,8 \\
\hline 10. Urediti kulturno-družabni klub soseske & 50,1 & 25,5 & 24,4 \\
\hline 11. Celovita toplotna izolacija stavb & 47,8 & 22,0 & 30,2 \\
\hline 12. Več »ekoloških otokov« & 47,3 & 24,7 & 28,0 \\
\hline
\end{tabular}

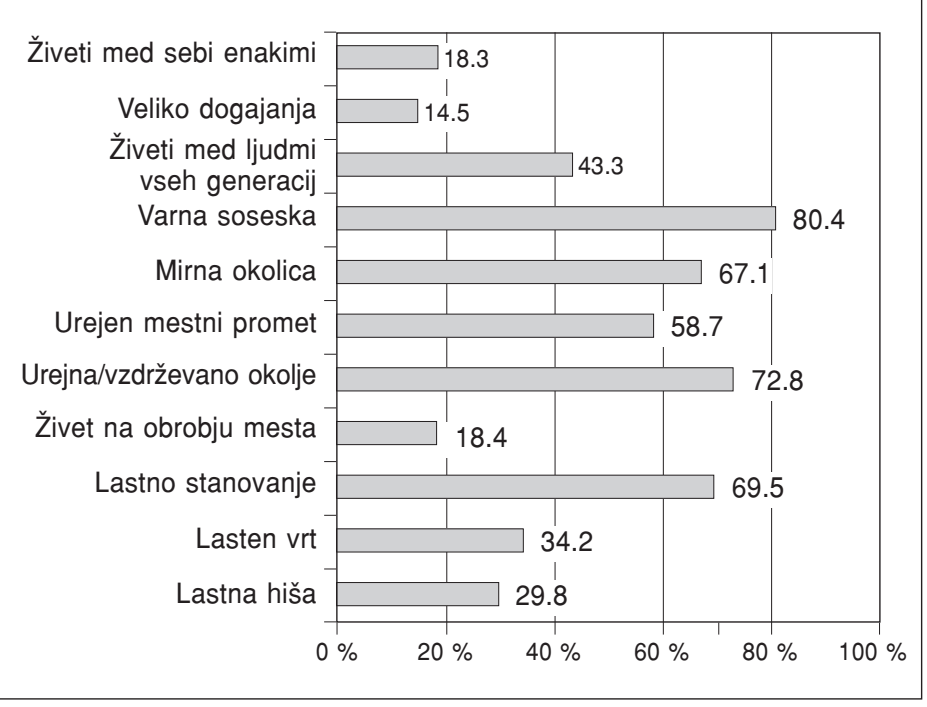

Graf 1: Kaj je za anketirance kakovost življenja v urbanem okolju? da ta (običajni) proces zniževanja kakovosti bivalnega okolja brez prenove ne velja za njihovo sosesko. To mnenje nekoliko izraziteje zastopajo starejši oziroma tisti, ki bivajo v soseski dlje časa.

V drugem kontrolnem vprašanju smo želeli testirati mnenje anketirancev o uporabi zdravju škodljivih materialov pri gradnji. Vprašanje se glasi »Včasih se pokaže, da so bili pri gradnji starejših stanovanjskih sosesk uporabljeni zdravju škodljivi materiali. Ali menite, da je vaša soseska tudi eden od takšnih primerov? « Anketiranci so odgovarjali dokaj pričakovano. Razdelili so se v tri po obsegu skoraj identične skupine in le manjšina je izbrala pesimistično možnost na lestvici (»gotovo je/gotovo ni«). Tako jih 36,5 odstotka meni, da to ni verjetno, 33,1 odstotka, da je verjetno, in 30,4 odstotka jih preprosto prizna, da ne vedo, kako je s tem pri njihovi soseski. Poglobljena analiza odgovora na to kontrolno vprašanje kaže, da gre bolj za osebne lastnosti posameznikov na osi pesimisti-optimisti kot pa za pogled, ki je posledica osebne stanovanjske zgodovine ali demografskih dejstev.

V vsebinsko temeljnem vprašanju o prenovi smo našteli 26 možnosti (glej vprašanje št. 17 $\mathrm{v}$ prilogi), ki so po mnenju interdisciplinarne projektne skupine razvojno kritične in s tem lahko predmet prenove. Ob tem smo anketirancem dali še možnost dodatnega odprtega vprašanja. V preglednici 5 je podanih prvih 12 izbir po stopnji pomembnosti za anketirance. Gre za izbire, ki so jih praviloma - v več kot polovici primerov - izbrali anketiranci kot potrebne prenove ali ureditve na novo.

Za razumevanje vrstnega reda izbir pomembnosti prenove za anketirance je ključno vprašanje »Kako pomembne so za vas naštete kvalitete življenja $v$ urbanem okolju? « V grafu 1 so navedene deleži izbir »zelo pomembno«, kar je bila več kot polovična izbira anketirancev v petih primerih, na štiristopenjski lestvici (»popolnoma nepomembno, delno nepomembno, še kar pomembno, zelo pomembno«).

Iz grafa je razvidno, da anketiranci cenijo kot temelje kakovostnega življenja v urbanem okolju predvsem bivanje v svojem stanovanju v varni in mirni soseski z urejenim in vzdrževanim okoljem, zato ne preseneča, da poudarjajo ureditev otroških igrišč in jav- 
nih zelenih površin ter povečanje varnosti $\mathrm{v}$ soseski, kjer je sicer primerjalno precej malo vandalizma.

Kot možni vir financiranja prenove smo v sklopu vprašanj o prenovi postavili tudi vprašanje »Pod katerimi pogoji bi bili za to, da se $v$ naselju zgradijo dodatna stanovanja? Prosimo, navedite pogoje (npr.: da zgradijo podzemne garaže, da se bolje uredi javni potniški promet, da izvajalci zagotovijo ugodne kredite za obnovo stavb ipd.) «. Na ponujeno možnost financiranja vsaj dela prenove $\mathrm{Z}$ novogradnjami so se anketiranci in stanovalci na splošno burno odzvali, kar se je pokazalo tako $v$ anketi, kjer je kar tri četrtine anketirancev izbralo možnost »pod nobenim pogojem «, kot tudi z množično udeležbo na delavnici, ki jo je povzročila predvsem ta predlagana možnost. Druga četrtina anketirancev, ki dopušča možnost dodatnih gradenj, je navedla 180 različnih pogojev. Pri tem moramo upoštevati, da jih je lahko vsak navedel več. V preglednici 6 podajamo pregled tematsko urejenih pogojev, ki so bili navedeni najmanj petkrat.

Iz navedenih pogojev je razvidno, da manjŠina, ki se načelno strinja $z$ gradnjo dodatnih stanovanj, želi v zameno predvsem ureditev problema parkiranja v soseski ter ugodne pogoje nakupa novih stanovanj. Rezultati križanj pa kažejo, da se nasprotovanje gradnji novih stanovanj povečuje s časom bivanja v soseski ter s starostjo stanovalcev. Možnost gradnje novih stanovanj bolj podpirajo anketiranci iz gospodinjstev s štirimi ali več osebami ter najemniki stanovanj, a tudi pri obeh navedenih skupinah delež podpore ne presega 40 odstotkov. Močno izraženo nasprotovanje je pogosto podkrepljeno tudi s sporočili izvajalcem in naročnikom raziskave ob koncu ankete, naj ne uničijo »ene še redkih kakovostnih sosesk v Ljubljani «.

Pri predlagani prenovi nas je seveda zanimalo tudi, kako bi bili pripravljeni anketiranci sodelovati, zato smo v sklop uvrstili vprašanje »Vzdrževanje in prenova soseske zahteva dodatna finančna sredstva. Ali bi bili vi pripravljeni:«, kjer smo ponudili štiri izbire. Odgovore podajamo v preglednici 7 .

Čeprav smo v vprašanje že v izhodišču vključili tudi vzdrževanje in ne le prenove, je delež anketirancev, ki nikakor niso pripravljeni vlagati v vzdrževanje in prenovo, precej ve- lik. Med tistimi, ki niso pripravljeni vlagati, je največ tistih, ki živijo v soseski manj kot šest let (44,4 odstotka), ter tistih, ki bivajo $\mathrm{V}$ njej 31 let ali več $(58,2)$. Glede na starostne skupine pa zavračajo vlaganja mlajši od 30 let (46,5 odstotka) in še izraziteje anketiranci, stari od 56 do 65 (50,7 odstotka) ter stari 66 let in več $(62,4)$.

Iz analize preostalih treh izbir ugotavljamo, da manjšino, ki bi bila pripravljena plačevati za vzdrževanje in prenovo, večinoma sestavljajo zaposleni, stari od 21 do 40 let, z višjo ali visoko stopnjo izobrazbe, ki bivajo v soseski od 6 do 30 let v gospodinjstvih, ki štejejo tri člane in več. S svojim delom bi bili pripravljeni sodelovati anketiranci s srednjo izobrazbo (44,2 odstotka) v starosti od 31 do 65 let in izstopajoče v skupini od 41 do 55 let $(34,1$ odstotka). S svojim znanjem pa bi pri vzdrževanju in prenovi sodelovali mlajši (do 40 let starosti) in bolj izobraženi, ki tudi praviloma bivajo manj časa v soseski.

Dejavnik, ki najizraziteje določa pripravljenost za sodelovanje ter načine sodelovanja pri vzdrževanju in prenovi, je skupni mesečni dohodek gospodinjstva. Ta je seveda odvisen predvsem od izobrazbe anketirancev oz. članov njihovega gospodinjstva ter tudi od velikosti gospodinjstev. Tako več kot polovica anketirancev, pri katerih skupni mesečni do-

Preglednica 6: Pogoji za gradnjo dodatnih stanovanj $(N=131)$

\begin{tabular}{|l|c|}
\hline \multicolumn{1}{|c|}{ Pogoj: } & Število navedb: \\
\hline Gradnja podzemne garaže & 37 \\
\hline Ugodni kreditni pogoji & 26 \\
\hline Ureditev parkirnih prostorov & 23 \\
\hline Obnovitev starih stavb & 19 \\
\hline Zgraditi garaže & 16 \\
\hline Ureditev LPP & 11 \\
\hline Izkoristiti podstrešja/nadzidava & 8 \\
\hline Več zelenih površin/igrišč/igral & 6 \\
\hline Ugodne cene stanovanj & 5 \\
\hline
\end{tabular}

Preglednica 7: Sodelovanje pri prenovi

\begin{tabular}{|l|c|}
\hline 1. Da, pripravljen sem plačati za vzdrževanje in prenovo soseske & $16,4 \%$ \\
\hline $\begin{array}{l}\text { 2. Pripravljen sem s svojim delom prispevati k vzdrževanju } \\
\text { in obnovi }\end{array}$ & $22,6 \%$ \\
\hline $\begin{array}{l}\text { 3. Pripravljen sem s svojim znanjem prispevati k vzdrževanju } \\
\text { in obnovi }\end{array}$ & $16,6 \%$ \\
\hline 4. Nisem pripravljen vlagati v vzdrževanje in prenovo soseske & $44,4 \%$ \\
\hline
\end{tabular}


hodek vseh članov gospodinjstva ne dosega 200.000 SIT, ni pripravljena vlagati v vzdrževanje in prenovo. Od vseh 514 sodelujočih, ki so bili pripravljeni odgovoriti na vprašanje o višini skupnega mesečnega dohodka na gospodinjstvo, zavzema skupina, ki ne dosega praga 200.000 SIT, 43,4 odstotka. Na drugi strani pa le četrtina anketirancev, kjer skupni družinski mesečni dohodki dosegajo 300.000 SIT ali več, ni pripravljena vlagati v vzdrževanje in prenovo. Ti sestavljajo slabo tretjino (30,9 odstotka) vseh, ki so odgovorili na vprašanje o skupnem mesečnem dohodku gospodinjstva.

Čeprav so deleži tistih, ki bi bili kakorkoli pripravljeni sodelovati pri vzdrževanju in prenovi, dokaj majhni, saj praviloma ne presegajo ene tretjine vseh anketirancev, so vseeno zadosten motivacijski kapital za nadaljevanje raziskovalnega projekta o prenovi v smeri izvedbe prenove. Ključni problem - ob izrazitem nezaupanju tako do MOL kot tudi do v raziskovalni projekt vključene interdisciplinarne skupine strokovnjakov - je predvsem finančna nezmožnost stanovalcev za (so)financiranje prenove, saj rezultati ankete kažejo, da je le približno tretjina anketirancev finančno sposobna podpreti vzdrževanje soseske na višji ravni in prenovo. (O problemu nezaupanja glej v Kos 2002: 40-42)

Sklop vprašanj o prenovi smo sklenili $\mathrm{Z}$ vprašanjem o reševanju problematike parkiranja. Desetina anketirancev je odgovorila, da to v soseski sploh ni problem. Gre za starejšo skupino, ki praviloma nima avtomobila. Med drugimi anketiranci, ki so lastniki osebnih avtomobilov, pa se kot rešitvi kažeta gradnja garažne hiše v soseski ali pa najem in odkup prostih garažnih boksov v sosednji Zupančičevi jami. Pri obojem pa pričakujejo anketiranci ugodne pogoje najema ali odkupa. Za najem in nakup garažnih boksov v sosednji soseski so bolj navdušeni starejši anketiranci, ki dlje bivajo v soseski v eno- ali dvočlanskih gospodinjstvih. Za gradnjo garažne hiše se bolj navdušujejo bolj izobraženi ter mlajši anketiranci, ki krajši čas bivajo tam. Z uvedbo lastniških parkirnih prostorov pa se spet strinjajo starejši stanovalci, ki dlje bivajo v soseski, ter anketiranci iz gospodinjstev $\mathrm{Z}$ več družinskimi člani. Vsekakor pa je reševanje problema parkiranja po mnenju anketirancev ena od osrednjih problematik, s katero bi se morala ukvarjati prenova in poskus izboljšanja ka- kovosti bivalnega okolja, kar se izraža v odgovorih na celotni vprašalnik ter tudi v razpravi na delavnici v soseski.

\subsection{Kakovost stanovanja in njegovo vzdrževanje}

Tretji sklop vprašanj $\mathrm{v}$ anketi se nanaša na bivanjsko kakovost stavbe in predvsem stanovanja, v katerem biva anketiranec, vključno $\mathrm{z}$ vprašanji o prenovah na objektu in $\mathrm{v}$ stanovanju v zadnjih petih letih ter o načrtovanih prenovah. Sklop smo začeli s podatki o velikosti in tipu stanovanj. Na vprašanje o velikosti je odgovorilo 517 anketirancev. Drugi niso vedeli tega podatka. Praviloma gre pri manjkajočih odgovorih za anketirance, ki živijo v najemnih stanovanjih.

Podatki o velikosti in tipu stanovanj, ki smo jih dobili $\mathrm{z}$ anketo, se v bistvenih karakteristikah ujemajo z dejanskim stanjem, ki so ga dobili kolegi raziskovalci z Urbanističnega inštituta RS z analizo načrtov ter inventarizacijo stanja na terenu. Za sosesko je značilna dokaj majhna gostota števila prebivalcev ob precej veliki gostoti števila stanovanjskih enot. Tako je po anketnih rezultatih ugotovljena povprečna velikost stanovanja 54 kvadratnih metrov (s standardnim odklonom 14,7). Minimalna velikost znaša 18 kvadratnih metrov, maksimalna, navedena $\mathrm{v}$ anketi, pa 120 kvadratnih metrov. Po številu sob prevladujejo dvosobna (43,6 odstotka) in enosobna stanovanja (35,3 odstotka). Delež večjih je precej majhen (14 odstotkov).

Glede na analizo demografskih značilnosti stanovalcev po posameznih tipih stanovanj je razvidno, da v večjih stanujejo anketiranci $z$ višjo izobrazbo in s tem tudi povezanimi večjimi mesečnimi dohodki gospodinjstva ter anketiranci, ki že dlje bivajo v soseski. V stanovanjih z manjšo kvadraturo (do 39 in do 49 kvadratnih metrov) bivajo večinoma mlajši anketiranci in anketiranci, ki živijo v njej manj kot pet let, ter najemniki. Med najemniki v manjših stanovanjih prevladuje študentska populacija, ki sicer v celoti gledano ni zelo številna, a je, glede na izjave udeležencev delavnice, moteča za prebivalce »staroselce«. Moti jih predvsem primerjalno večja stopnja motoriziranosti najemnikov študentov. Zanimiv je tudi podatek, da od vseh anketirancev, ki živijo sami, polovica biva $\mathrm{v}$ stanovanjih, večjih od 50 kvadratnih 
metrov, in slaba tretjina $(31,4$ odstotka $) \mathrm{v}$ stanovanjih, večjih od 60 kvadratov. Le malo gospodinjstev s tremi ali več člani biva $\mathrm{v}$ manjših stanovanjih. Glede na rezultate ankete lahko rečemo, da stanovanjska stiska, ki bi jo povzročila nezadostna velikost stanovanj, ni izrazita.

V nadaljevanju sklopa smo anketirance vprašali o zadovoljstvu $\mathrm{z}$ lastnostmi njihovega stanovanja. Kot je razvidno iz preglednice 8 , so večinoma »še kar zadovoljni « ali »zelo $z a$ dovoljni s stanovanjem na splošno, lego prostorov, osvetljenostjo stanovanja ter infrastrukturno opremljenostjo. Največ nezadovoljstva izražajo s kakovostjo gradnje ter številom sob.

S stanovanjem v celoti so najbolj zadovoljni upokojenci, saj jih le osmina ni zadovoljna z njim na splošno, ter anketiranci z najmanjšimi dohodki. $Z$ velikostjo stanovanja pa so nezadovoljni mlajši anketiranci, ki tudi prebivajo krajši čas v soseski ali pa že od nekdaj živijo v soseski, ter anketiranci, ki bivajo v gospodinjstvi s štirimi in več člani.

Poleg zadovoljstva s stanovanjem nas je zanimala opremljenost stanovanja, kjer se je ob dejstvu, da večina ima priključek na KTV (83,3 odstotka) in večinoma tudi balkon $(80,3$ odstotka), pokazal tudi relativno velik delež gospodinjstev $\mathrm{z}$ dostopom do interneta $(54,8$ odstotka). Manj pa je stanovanj z zvočno izoliranimi okni $(27,1$ odstotka) ter manj kot desetina s klimatsko napravo (9,1 odstotka).

Pri analizi dostopa do interneta ugotavljamo, da gre za infrastrukturo, ki jo najbolj določata starost in izobrazba anketirancev. Tako ima kar 69 odstotkov sodelujočih, mlajših od 30 let, 62,5 odstotka anketirancev, starih od 31 do 40 let, in 64,9 odstotka anketirancev, starih od 41 do 55, v svojem stanovanju dostop do interneta, medtem ko ta delež znaša pri anketirancih, starejših od 66 let, le 25,7 odstotka, kar pa je, če primerjamo s slovenskim povprečjem, vseeno precej velik delež informatizacije starejše populacije (glej Trček 2004/2005). Od manjšine, ki si je vgradila klimatsko napravo, je dohodkovno največja kategorija anketirancev, ki živijo v soseski od 16 do 30 let. Podobno je pri oknih z zvočno izolacijo.

V koncu sklopa o kakovosti stanovanja smo postavili še blok vprašanj, ki so se nanašala na prenovitvena dela $\mathrm{v}$ zadnjih petih letih $\mathrm{v}$ stavbi in stanovanju. Na stavbah so stanoval- ci najpogosteje prenavljali strehe ( 48,6 odstotka), omrežje KTV $(48,5)$ ter stopnišča in vhode $(42,1)$. S prenovo stavbe so zadovoljni. V stanovanjih so ob močno najpogostejšem pleskanju (83,9 odstotka) v zadnjih petih letih menjali radiatorje (37 odstotkov) in okna (35,7 odstotka), se priključili na internet $(34,2)$ ter prenavljali kuhinje $(37,3)$ in kopalnice $(30,2)$. Analize prenov kažejo, da so bila prenovitvena dela $v$ stanovanjih pogostejša $v$ gospodinjstvih $\mathrm{z}$ več družinskimi člani ter $z$ večjimi dohodki.

V naslednjih petih letih pa po izjavah anketirancev, ki so odgovorili na vprašanje, načrtujejo prenovitvena dela na 40,2 odstotka stavb in v 59,3 odstotka stanovanj. Od navedenih načrtovanih del na stavbi je največ prenov fasad $(32,2$ odstotka), streh $(13,7)$ in stopnišč $(9,8)$. Pri načrtovanih delih v stanovanju pa ob pleskanju (12,7 odstotka) najpogosteje navajajo še: zamenjavo oken (19,3 odstotka), prenovo kopalnic $(17,2)$, zamenjavo podov $(5,3)$ in vgradnjo klimatskih naprav $(4,9)$. Pri anketirancih, ki so navedli, zakaj v naslednjih petih letih ne načrtujejo prenovitvenih del na stavbi in v stanovanju, sta ob odgovoru $\gg n i$ potrebelje bilo že prenovljeno/je v redu« izrazita pomanjkanje financ ter problem soglasja stanovalcev pri prenovi stavb.

Če gledamo sklop vprašanj o kakovosti stanovanj in njihovi prenovi v celoti, na eni strani ugotavljamo, da so anketiranci večinoma zadovoljni s kakovostjo svojega stanovanja, na drugi pa, da je dohodek gospodinjstva dejansko tisti glavni dejavnik, ki določa tako (infrastrukturno) kakovost stanovanja kot

Preglednica 8: Zadovoljstvo s stanovanjem

\begin{tabular}{|l|c|c|c|c|}
\hline & $\begin{array}{c}\text { Zelo } \\
\text { nezado- } \\
\text { voljen } \\
\%\end{array}$ & $\begin{array}{c}\text { Delno } \\
\text { nezado- } \\
\text { voljen } \\
\%\end{array}$ & $\begin{array}{c}\text { Še kar } \\
\text { zadovo- } \\
\text { Ijen } \\
\%\end{array}$ & $\begin{array}{c}\text { Zelo } \\
\text { zadovo- } \\
\text { Ijen } \\
\%\end{array}$ \\
\hline 1. Lego stanovanja & 4,3 & 12,0 & 45,0 & 38,7 \\
\hline 2. Njegovo velikostjo & 10,3 & 18,4 & 47,6 & 23,8 \\
\hline 3. Razporeditvijo prostorov & 10,2 & 22,2 & 45,4 & 22,2 \\
\hline 4. Številom sob & 12,2 & 27,0 & 42,3 & 18,5 \\
\hline 5. Kakovostjo gradnje & 20,7 & 35,4 & 36,2 & 7,7 \\
\hline 6. Osvetljenostjo stanovanja & 4,5 & 12,5 & 50,6 & 32,5 \\
\hline 7. Infrastrukturno opremljenostjo & 2,5 & 11,6 & 51,6 & 34,3 \\
\hline (elek., toplovod, KTV ...) & & & & \\
\hline 8. Vzdrževanostjo stanovanjske hiše & 10,5 & 25,6 & 51,1 & 12,8 \\
\hline 9. Stanovanjem na splošno & 1,9 & 11,9 & 67,2 & 19,0 \\
\hline
\end{tabular}


možnosti vzdrževanja in prenove. Ob tem pa so tudi premožnejši, bolj izobraženi in praviloma mlajši bolj kritični do kakovosti bivanja v soseski kot tudi pri ocenah kakovosti stanovanj, v katerih bivajo.

\subsection{Stanovanjske preference}

Zadnji tematski sklop vprašalnika je bil namenjen ugotavljanju stanovanjskih preferenc anketirancev. Pri tem nas je predvsem zanimalo, ali načrtujejo selitev ali pa si želijo reševati svojo stanovanjsko problematiko v soseski, čeprav je to trenutno glede na tamkajšnjo ponudbo skorajda nemogoče.

Na vprašanje »Ali se želite preseliti $v$ drugo stanovanje znotraj vaše soseske? « je velika večina anketirancev odgovorila $\mathrm{z}$ »nikakor ne (40,2 odstotka) in »verjetno ne $(43,9$ odstotka). Ta možnost pa se zdi verjetna 15,9 odstotka anketirancem. Znotraj soseske bi se preselila slaba četrtina tistih, ki bivajo v njej manj kot 16 let, ter tisti, ki od nekdaj živijo v njej (17,4 odstotka). V obeh primerih gre pretežno za skupino sodelujočih, mlajših od 40 let. Podobni odgovori so bili na vprašanje »Se želite preseliti $v$ drugo stanovanjsko sose$s k o ?$ \& Dobra petina razmišlja o tem. Po demografskih karakteristikah gre za skoraj identično skupino kot pri tistih, ki bi se želeli preseliti znotraj soseske. Opazna je le skupina anketirancev $z$ največjimi dohodki in najvišjo stopnjo izobrazbe. Odgovori na navedeni vprašanji nam kažeta, da bi z ustrezno politiko prenove, ki bi vključevala nadzidave in dozidave, zagotovili večini, ki izraža željo po selitvi, rešitev stanovanjske problematike znotraj soseske, ne da bi pri tem bistveno povečali število prebivalcev ter gostoto zazidave.

V naslednjem vprašanju, ki se nanaša že na morebitno načrtovanje selitve, je 16,1 odstotka anketirancev odgovorilo, da jo že načrtujejo. Med razlogi najpogosteje navajajo: da si želijo večje stanovanje (16,6 odstotka), da se bo velikost družine spremenila $(8,7)$, da nameravajo kupiti svojo hišo $(9,6)$ ali svoje stanovanje $(8,7)$ ter da si želijo bolj urejeno $(7,9)$ in varno $(6,6)$ stanovanjsko okolje. Selitev načrtuje četrtina anketirancev, ki biva $\mathrm{v}$ soseski manj kot pet let ali od šest od 15 let, in četrtina anketirancev v starostnih skupinah do 30 let in od 30 do 40 let ter četrtina od anketirancev z najvišjo stopnjo izobrazbe. $\mathrm{S}$ povečevanjem starosti pa delež tistih, ki načrtujejo selitev, izrazito pada in tako se med starejšimi od 56 let namerava odseliti le sedem anketirancev. Iz soseske se prav tako namerava odseliti 40 odstotkov najemnikov. Dejavnik, ki najbolj določa tiste, ki načrtujejo odselitev, je skupni mesečni dohodek gospodinjstva, saj se namerava odseliti kar 37 odstotkov anketirancev iz skupine z največjimi dohodki (več kot 400.000 SIT).

Med anketiranci, ki ne razmišljajo o selitvi, so najpogostejši razlogi, da bodo ostali v soseski, ob dejstvu, da se »v tem okolju dobro počutim « (15 odstotkov), še: bližina središča mesta (16,2 odstotka), bližina železniške in avtobusne postaje ( 9,1 odstotka), mirnost soseske $(8,9)$, bližina delovnega mesta $(7,4)$ ter dejstvo, da bi bilo drugo stanovanje predrago $(8,9)$. Če odgovore o stanovanjskih preferencah primerjamo $\mathrm{z}$ odgovori o navezanosti na sosesko, lahko postavimo tezo, da gre pri veliko anketirancih prej za ujetost $\mathrm{v}$ sosesko, ker nimajo finančnih virov za izboljšanje kakovosti svojega bivalnega okolja. Izjema so tisti, ki bivajo v njej 31 let in več. Večinoma gre v tej skupini za upokojence, ki so večinoma zadovoljni s svojim stanovanjem in bivalnim okoljem na splošno.

\subsection{Demografske značilnosti in projekt prenove}

Če primerjamo demografske značilnosti anketirancev z zadnjimi dosegljivimi statističnimi podatki o stanovalcih soseske (popis leta 1991) ter $z$ informacijami s terena iz pogovorov s stanovalci ter upravniki stavb, lahko rečemo, da dobljeni naključni vzorec 553 naključno izbranih anketirancev ustreza glavnim značilnostim v soseski bivajoče populacije. V nadaljevanju sklopa o demografiji zato navajamo le nekatere za nadaljevanje projekta prenove pomembnejše demografske značilnosti, ki jih bo treba upoštevati pri morebitnem načrtovanju politike in izvedbe prenove.

Če najprej pogledamo dolžino bivanja v soseski, vidimo, da kar 40,5 odstotka vseh anketirancev biva v soseski »31 let in več« ali pa že »od nekdaj živi tu«. Ob tem jih slaba tretjina (31,3 odstotka) biva v njej manj kot pet let ter 13,6 odstotka od pet do 15 let. Večina živi ali v najemnih ali v neprofitnih stanovanjih MOL. Gre za dve veliki skupini, ki sta $v$ svojih težnjah glede reševanja stanovanjske problematike pogosto na nasprotnih 
straneh. »Staroselci« si predvsem želijo, da soseska ostane takšna, kot je, ter da se uredita okolica in problem parkiranja. Druga skupina pa si želi ob tem izboljšati še svoj stanovanjski status.

Skupina anketirancev, ki biva $v$ soseski že dlje, večinoma živi v gospodinjstvu $z$ dvema članoma ali sami. Iz ankete je vidno dejstvo, na katero so nas opozarjali pri pogovorih na terenu ter pri pogovorih z upravitelji, da je povprečna velikost gospodinjstva malo manj kot dva člana. Tako po podatkih iz ankete živi četrtina anketirancev sama (24,9 odstotka), v gospodinjstvih $\mathrm{z}$ dvema članoma pa kar 34 odstotkov, preostali dve petini odpadeta na tričlanska (21,1 odstotka) ter štiri- in veččlanska gospodinjstva (20,1 odstotka). Ob tem je treba opozoriti, da sestavljajo gospodinjstva s petimi osebami le tri odstotke vseh v anketo vključenih gospodinjstev.

Po starosti je med anketiranci polovica mlajša od 41 let (25,5 odstotka do 30 let in 25,5 odstotka od 31 do 40 let), sledi 16 odstotkov anketirancev, starih od 41 do 55 let, ter 15 odstotkov anketirancev, starih od 56 do 65 let. Starejših od 65 let je 18 odstotkov. Povprečna starost anketirancev je 45 let, povprečna starost druge osebe $\mathrm{v}$ gospodinjstvu pa 40 . Povprečne starosti preostalih oseb, ko gre za tričlanska in večja gospodinjstva, so od 18 do 20 let, kar pomeni, da gre pri večgeneracijskih gospodinjstvih prevladujoče za gospodinjstva s starši in enim ali dvema otrokoma, ki sta na prehodu iz najstniških let. Stanje je drugačno v neprofitnih stanovanjih MOL, kjer prevladujejo mlajše družine.

Glede na starostno strukturo tudi ni presenetljiva delovna aktivnost anketirancev, kjer je ob 48,3 odstotka zaposlenih kar 31,6 odstotka upokojencev ter 11,8 odstotka šolarjev in 8,3 preostalih. Med njimi je brezposelnih in zgolj priložnostno zaposlenih 5,3 odstotka.

$\mathrm{Za} \mathrm{(so)financiranje} \mathrm{prenove} \mathrm{je} \mathrm{gotovo} \mathrm{po-}$ memben tudi podatek o skupnem mesečnem dohodku vseh članov gospodinjstva v zadnjem mesecu. Na vprašanje je odgovorilo visokih 93 odstotkov anketirancev. Glede na rezultate in izhajajoč iz domneve, da je 300.000 SIT in več mesečnega dohodka tista meja, ki bi omogočila prenovo, ki bi jo financirali stanovalci, je razvidno, da je kar 69,1 odstotka vseh anketirancev ne dosega. Ob tem je razvidno, da skoraj slaba polovica
(43,4 odstotka) vseh ne dosega 200.000 SIT mesečnega dohodka na gospodinjstvo.

Če dohodkovno stratifikacijo gospodinjstev povežemo $z$ odgovori na vprašanja o verjetnih in načrtovanih selitvah, lahko sklenemo, da je verjeten scenarij izselitve tistih anketirancev, ki si to lahko finančno privoščijo. To pomeni, da bodo njihove prostore zasedli finančno manj uspešni novi stanovalci ali pa bodo zlasti manjša stanovanja namenjena najemu, kar se že dogaja. Brez izvedene celovite prenove, ki bo vključevala tudi sprejemljivo finančno-kreditno politiko, lahko iz ocene možnosti vzdrževanja in prenov stanovalcev predvidevamo, da se bo v naslednjem desetletju zmanjšala kakovost vzdrževanja ter s tem posledično padla vrednost tamkajšnjih nepremičnin. Nezadovoljni stanovalci soseske $\mathrm{v}$ degradaciji pa bodo predvsem z zavračanjem in protesti blokirali kakršnakoli vključevanja soseske v celovitejše načrte prenove MOL.

\section{Sklepne ugotovitve}

Ker so bile v članku že podrobno predstavljeni rezultati ankete in sekundarnih analiz, podajamo v sklepu za nadaljevanje projekta prenove ključne ugotovitve, ki bi jih bilo treba upoštevati kot strokovne podlage pri načrtovanju izvedbe prenove:

- Anketiranci ocenjujejo sosesko kot bolj urejeno, a ne tako zelo drugačno od sosesk v Ljubljani. Na eni strani se zavedajo dokaj majhne gostote gradnje ter obilja zelenih površin kot primerjalnih odlik, na drugi strani pa so ob stihijskem parkiranju ravno slabo vzdrževanje zelenih povrŠin, vključno z otroškimi igrišči, ter onesnaženje ulic s smetmi in pasjimi iztrebki tisto, kar po njihovem mnenju zmanjšuje potencialno (primerjalno) kakovost bivalnega okolja.

- Kljub pogostim lirično navdihnjenim opisom odlik »zelene in mirne soseske« oziroma »ob Prulah edine še neuničene soseske $\mathrm{v}$ središču Ljubljane « v bližini »grozne Zupančičeve jame« v sklepnem vprašanju je presenetljivo nizka stopnja povezanosti s sosesko. Z njo se identificirajo starejši prebivalci, ki praviloma dlje bivajo v njej, ter zelo opazno anketiranci, 
ki že ves čas živijo v njej. Praviloma gre pri obeh skupinah za lastnike stanovanj in ne za najemnike ali podnajemnike.

- Skoraj dve tretjini anketirancev se zavedata nujnosti prenove, dobra tretjina pa meni, da ni potrebna, ob tem pa se jih 14,4 odstotka ne more odločiti. V skupino, ki meni, da je prenova potrebna, spadajo ob tistih, ki že od rojstva bivajo v soseski, predvsem mlajši, delovno aktivni anketiranci, ki so praviloma tudi iz dohodkovno bolje stoječih tri- in štiričlanskih dvogeneracijskih gospodinjstev, ter tisti, ki bivajo $\mathrm{v}$ soseski manj kot 15 let. Med anketiranci, ki menijo, da prenova (sploh) ni potrebna, pa prevladujejo starejši in upokojenci iz eno- in dvočlanskih gospodinjstev ter anketiranci $z$ manjšimi dohodki ter nižjo doseženo stopnjo izobrazbe. Ti so tudi manj kritični pri oceni lastnosti soseske in tudi primerjalno bolj zadovoljni s stanovanjem, v katerem bivajo, od zagovornikov prenove.

- Pri prenovi bi bili pripravljeni osebno sodelovati anketiranci, ki so zaposleni in od nekdaj živijo v soseski ali pa v njej prebivajo od šest do 30 let, spadajo v gospodinjstva $Z$ večjim skupnim mesečnim dohodkom ter bivajo v lastniških ali neprofitnih stanovanjih v tri- in veččlanskih gospodinjstvih. Med starostnimi skupinami je opazna skupina anketirancev, starih od 31 do 40 let, ki izraža veliko pripravljenost za osebno sodelovanje $\mathrm{v}$ prenovi. Stopnja pripravljenosti se povečuje tudi s stopnjo izobrazbe. Med polovico, ki ne ve oziroma o tem še ni razmišljala, je nekoliko več starejših, manj izobraženih in tistih, ki živijo manj časa v soseski.

- Skoraj dve tretjini anketirancev menita, da običajni proces zmanjševanja kakovosti bivalnega okolja brez prenove ne velja za njihovo sosesko. Tako nekoliko izraziteje menijo starejši oziroma tisti, ki bivajo $\mathrm{v}$ njej dlje.

- Za razumevanje vrstnega reda izbir pomembnosti pri prenovi, v kateri bi sodelovali anketiranci, je ključno vprašanje »Kako pomembne so za vas naštete prednosti življenja v urbanem okolju? « Anketiranci kot »zelo pomembne « prednosti navajajo: bivanje v svojem stanovanju v varni in mirni soseski $z$ urejenim in vzdrževanim okoljem, zato ne preseneča, da poudarjajo ureditev otroških igrišč in javnih zelenih površin ter povečanje varnosti v soseski, v kateri je sicer primerjalno dokaj malo vandalizma.

- Na ponujeno možnost financiranja vsaj dela prenove z novogradnjami so se anketiranci in stanovalci zelo burno odzvali, kar se je pokazalo tako $\mathrm{v}$ anketi, kjer je kar tri četrtine anketirancev izbralo možnost »pod nobenim pogojem «, kot tudi z množično udeležbo na delavnici, ki jo je povzročila predvsem ta predlagana možnost.

- Manjšina, ki se načelno strinja z gradnjo dodatnih stanovanj, želi v zameno predvsem ureditev problema parkiranja v soseski ter ugodne pogoje nakupa novih stanovanj. Nasprotovanje gradnji novih stanovanj se povečuje s časom bivanja v soseski ter starostjo stanovalcev.

- Dejavnik, ki najizraziteje določa pripravljenost za sodelovanje ter načine sodelovanja pri vzdrževanju in prenovi, je skupni mesečni dohodek gospodinjstva. Ta je seveda odvisen predvsem od izobrazbe anketirancev oz. članov njihovega gospodinjstva ter tudi od velikosti gospodinjstev.

- Čeprav so deleži anketirancev, ki bi bili kakorkoli pripravljeni sodelovati pri vzdrževanju in prenovi, precej majhni, saj praviloma ne presegajo tretjine vseh anketirancev, so vseeno začetni motivacijski kapital za nadaljevanje raziskovalnega projekta o prenovi v smeri izvedbe prenove.

- Ključni problem - ob izrazitem nezaupanju tako do MOL kot tudi do interdisciplinarne skupine strokovnjakov, vključene $\mathrm{v}$ raziskovalni projekt - je predvsem finančna nezmožnost (so)financiranja prenove, pri kateri bi sodelovali stanovalci, saj rezultati ankete kažejo, da je le približno tretjina finančno sposobna podpreti vzdrževanje soseske na višji ravni in prenovo.

- Brez izvedbe prenove je verjeten scenarij izselitve anketirancev, ki si bodo to lahko finančno privoščili. To pomeni, da bodo njihove prostore zasedli finančno manj uspešni novi stanovalci ali pa bodo zlasti manjša stanovanja namenjena najemu, kar se v soseski že dogaja. 
- Brez izvedene celovite prenove, ki bo vključevala tudi sprejemljivo finančnokreditno politiko, se bo v naslednjem desetletju zmanjšala kakovost vzdrževanja ter s tem posledično padla vrednost nepremičnin. Nezadovoljni stanovalci soseske $\mathrm{v}$ degradaciji bodo z zavračanjem in protesti, kar se je že zelo jasno pokazalo pri izvedbi delavnice, blokirali vključevanje soseske v celovitejše načrte prenove, ki bi jo izvedla MOL.

- Glede na rezultate ankete ter analize pogovorov s stanovalci na delavnici predlagamo postopno izvedbo prenove, kjer bi najprej prenovljeni deli soseske $v$ prihodnje igrali motivacijsko vlogo za pridobivanje naklonjenosti prenovi še ne prenovljenih delov.

- Kot sprejemljiv ter izvedbeno obvladljiv začetni kare prenove se nam zdi četvorček blokov na Črtomirovi ulici (Črtomirova 2, $3,4,5)$. V predlaganem kareju - po izjavljanju predstavnikov stanovalcev - že sami razmišljajo o nujnosti prenove fasad in uskladitve različnih tipov zastekljevanja balkonov, zato predlagamo, da MOL v prvi fazi izvedbe prenove s sistemom primerjalno ugodnejših kreditov in sofinanciranjem pomaga izvesti temeljitejšo prenovo tega kareja. Ob tem pa bi bilo treba v prvi fazi urediti še problem parkiranja na vogalu Topniške in Vilharjeve, kjer je tudi največja gostota stanovanj ter mirujočega prometa.

Doc. dr. Franc Trček, univ. dipl. soc., Univerza v Ljubljani, Fakulteta za družbene vede, Ljubljana E-pošta: franc.trcek@fdv.uni-lj.si

Viri:

Kos, Drago (2002) Praktična sociologija za načrtovalce in urejevalce prostora. Ljubljana: Fakulteta za družbene vede (Knjižna zbirka Teorija in praksa).

Kos, Drago, in dr. (2004) Reurbanizacija stanovanjskih območij v mestnem jedru (Raziskovalni projekt Re-Urban Mobil): Zaključno poročilo. Ljubljana, Fakulteta za družbene vede (IDV) in Mestna občina Ljubljana.

Thompson, Steven K. (2002) Sampling. New York: Wiley.

http://www.cem.itesm.mx/dacs/publicaciones/logos/ant eriores/n42/ftrcek. html

Trček, Franc (2004/2005) E-Ljubljana: new space for active political participation. Razón y palabra (Online). diciembre 2004/enero 2005, no. 42. 